\title{
Ruptured aneurysm: therapy of abdominal compartment syndrome post EVAR
}

\author{
Vittorio Alberti, Pierluigi Costa, Stefano Fazzini, Eugenia Serrao, Sonia Ronchey, Nicola Mangialardi \\ From XXIII Annual Meeting of the Italian Society of Geriatric Surgery \\ Lecce, Italy. 2-4 December 2010
}

\section{Background}

Endovascular treatment of ruptured abdominal aortic aneurysms (r-EVAR) has the potential to offer improved outcomes. A frequent cause of post-operative mortality following ruptured aortic aneurysm repair is multiorgan failure (MOF) as a consequence of abdominal compartment syndrome (ACS). We reviewed our experience to identify predisposing factors for ACS (Fig. 1) and a way for its treatment.

\section{Materials and methods}

From January 2005 to December 2009, 53 patients underwent emergent endovascular repair of r-AAA. We mainly used bifurcated prostheses (44 patients), apart from 5 cases of aorto-uni-iliac device and 4 cases of straight endografts. Nine patients developed ACS and

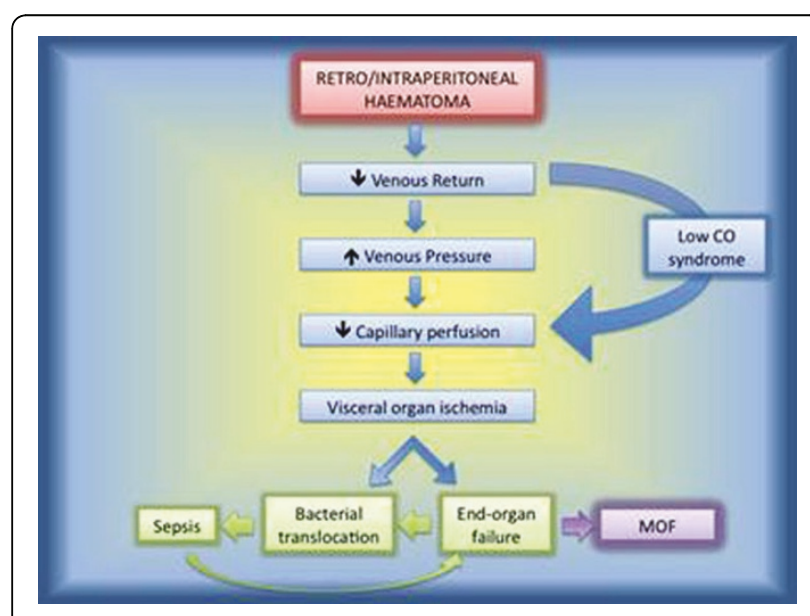

Figure 1 Chain of events triggered by retroperitoneal haematoma.

\footnotetext{
* Correspondence: vittorioalberti@libero.it

Unit of Vascular Surgery, San Filippo Neri Hospital, Roma, Italy

Full list of author information is available at the end of the article
}

were submitted to abdominal decompression by retroperitoneal surgical drainage (Fig. 2).

\section{Results}

Thirty-day mortality was $22.6 \%$ (12/53). Early mortality was recorded in unstable patients only. Stable patients (24) had no mortality in the first 30 days. Among patients who underwent retro-peritoneal drainage, the 30 -day mortality rate was $33.3 \%(3 / 9)$. At a median follow up of 34 months $(33.8+17.0) 3$ patients died of aneurysm or procedure related causes.

\section{Conclusions}

One of the priorities in the management of r-EVAR is to prevent and eventually treat the ACS. A surgical evacuation of the retroperitoneal hematoma through extraperitoneal access has considerable advantages, mainly in high risk and older patients. In r-EVAR the particular

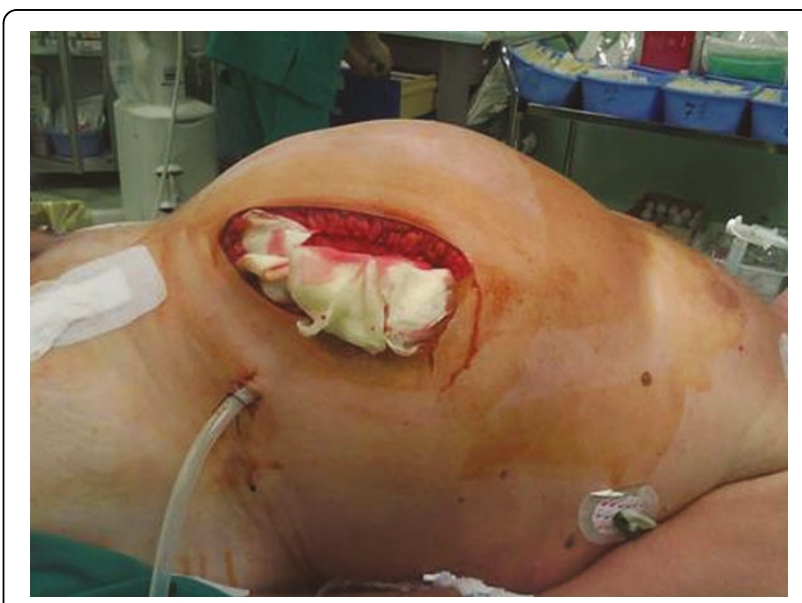

Figure 2 Surgical retroperitoneal access.

(c) 2011 Alberti et al; licensee BioMed Central Ltd. This is an open access article distributed under the terms of the Creative Commons 
factor is the retroperitoneal hematoma. Therefore we perform abdominal decompression via retroperitoneal access.

Published: 24 August 2011

\section{References}

1. Marin ML, Veith FJ, Cynamon J, Sanchez LA, Lyon RT, Levine BA, et al: Initial experience with transluminally placed endovascular grafts for the treatment of complex vascular lesions. Ann Surg 1995, 222:449-65.

2. Mastracci TM, Garrido-Olivares L, Cinà CS, Clase CM: Endovascular repair of ruptured abdominal aortic aneurysms: a systematic review and metaanalysis. J Vasc Surg 2008, 47(1):214-221.

3. Ten Bosch JA, Teijink JA, Willigendael EM, Prins MH: Endovascular aneurysm repair is superior to open surgery for ruptured abdominal aortic aneurysms in EVAR-suitable patients. J Vasc Surg 2010, 52(1):13-8.

doi:10.1186/1471-2318-11-S1-A1

Cite this article as: Alberti et al:: Ruptured aneurysm: therapy of abdominal compartment syndrome post EVAR. BMC Geriatrics 201111 (Suppl 1):A1.

\section{Submit your next manuscript to BioMed Central} and take full advantage of:

- Convenient online submission

- Thorough peer review

- No space constraints or color figure charges

- Immediate publication on acceptance

- Inclusion in PubMed, CAS, Scopus and Google Scholar

- Research which is freely available for redistribution

Submit your manuscript at www.biomedcentral.com/submit
Ciomed Central 